\title{
Factors Influencing Citizen's Adoption of M-government: The Case of Saudi Arabia
}

\author{
Afnan Elmouzan ${ }^{1} \&$ Muna Alhammad ${ }^{1}$ \\ ${ }^{1}$ College of Business Administration, King Saud University, Riyadh, Saudi Arabia \\ Correspondence: Muna Alhammad, College of Business Administration, King Saud University, Riyadh 11451, Saudi \\ Arabia.
}

Received: August 19, 2020

Accepted: September 19, 2020

Online Published: September 26, 2020

doi:10.5430/jms.v11n3p43

URL: https://doi.org/10.5430/jms.v11n3p43

\begin{abstract}
Governments across the world are pushed towards the provisioning of mobile government (m-government) services. However, the development of m-government services will not drive the expected benefits unless citizens' accept the use of these services. Literature shows that there is a paucity of studies on factors impacting citizens' acceptance and use of m-government services in Saudi Arabia. This paper proposed a conceptual model extending the Unified Theory of Acceptance and Use of Technology (UTAUT) model to consider other relevant factors, such as awareness and information quality, that can impact citizens' adoption of m-government applications. A survey questionnaire was developed and a total of 264 responses of Saudi citizens were collected and analysed using Partial Least square (PLS). The results indicate that social influence, performance expectancy, and effort expectancy are the factors that have significant impact on citizens behavioural intention to use m-government services, accounting for $57 \%$ of the variability, while citizens' awareness and information quality have no impact. Our findings can be used to stimulate the use of m-government services. The findings of this study suggest that decision makers on governments agencies and developers of m-government services should emphasis the role of social strategies to allow people to incentivise each other to use m-government services, clarify the benefits of using m-government services, and reduce the effort required for using m-government services.
\end{abstract}

Keywords: M-government, adoption, UTAUT, acceptance, developing countries, Saudi Arabia

\section{Introduction}

With the advancement of information and communication technologies (ICT), governments across the world are competing to deliver high-quality online services. This movement, represented by the development of e-government portals, led to delivering faster and more convenient services for citizens as well as an overall reduction of cost and improvement of government services efficiency (Abu-Shanab and Haider, 2015). Isaac (2007) defined electronic government as governments' use of technology, particularly Web-based Internet applications, to enhance the delivery of government information and services to citizens, business partners, employees, agencies, and other government entities. On the other hand, mobile government (m-government) is the recent and apparent evolutionary course that is more compatible and a dynamic subdivision of e-government due to its unique features that are linked with the use of a wireless communication system such as real-time interaction, time and location, convenience, versatility, customization and mobility (Shahzad et al., 2019). The implementation of e-government services and its predecessor m-government services help to establish transparent transactions and build more confident interactions between citizens and government as well as reducing the corruption occurrence since there is more control over resources. Moreover, as government data is stored in digital form, it makes it easier for governments and citizens to reach data from anywhere and whenever needed (Al-Khateeb et al., 2015). Additionally, offering government services online helps simplify the information exchange among the employees of the organization and helps to flatten the hierarchies (Fang, 2002; Laynea and Leeb, 2001).

The government of the Kingdom of Saudi Arabia (KSA) firmly believes in the enormous benefits that the e-government project will drive into the national economy (eGovernment, 2018). Accordingly, the first Saudi e-government program 'Yasser' was launched in 2005. 'Yesser' aims to enhance the productivity of the public sector and provide timely information with high accuracy; thus, leading to the provision of better services to individuals and businesses (Yesser, 2016). Nowadays, KSA is classified as 'High' on the e-governments development index of 
the United Nations (UN) and ranked among the top 20 countries in the provision of e-government services by the UN ("UN E-Government Survey 2018," 2018.). One of the main Saudi e-government portals is "Absher" portal, which concentrates on the delivery of the Ministry of Interior (MOI) services to both citizens and businesses. The portal aims to provide a one-stop platform to facilitate accessing all the MOI services online and making the procedures much easier. There are more than 160 e-services provided by Absher portal, which include passport services, traffic services, labour importation, Hajj permission, booking appointments on different government sectors, request missing documents, replacement documents, and other related services (“Absher", 2018.). Absher also has another version called 'Absher business' offering government to business transactions. Absher citizen's services are offered through three different channels: Absher website, Absher mobile application, and Absher Kiosk machines which are placed in different public places like shopping malls and government sectors. The use of mobile applications has become more attractive, recently, because of their simplicity, low-cost technology, inclusiveness of mobile phones, and the broad coverage of the mobile network which can reach remote areas that the infrastructure necessary for Internet services is hard to setup (Mengistu at el, 2009). Using mobile phones to access public services is becoming common among many citizens as it allows them to reach public services anywhere anytime.

In the KSA, 91\% of the citizens have access to the Internet (Bulletin of Individuals and Households' ICT Access and Usage Survey, 2018). However, the number of registered Absher users is only about 9 million users ("Figures and Statistics," 2017) out of 32 million citizens and resident in the country ("Media Center | General Authority for Statistics," 2017) which is considered low compared to the total number of the population. Little is known about what factors influencing citizens' adoption of m-government services in the KSA. Alshehri et al. (2013) previously studied citizens' acceptance of e-government services in general and the study was limited to testing the UTAUT without considering other context relevant factors. Factors impacting users' adoption of e-government will not necessarily impact users' adoption of $\mathrm{m}$-government. This raises a need for further investigation of factors impacting users' adoption in the context of m-government in the KSA. Therefore, the aim of this research was to evaluate factors that impact citizens' adoption of m-government services in the KSA.

This paper starts with reviewing relevant theories of technology adoption followed by presenting the research model and the proposed hypotheses. Then, the research methodology will be explained, and the study results will then be presented. Finally, the implications and limitations of the study will be demonstrated and followed by recommendations for future research.

\section{Theories of Technology Adoption}

Several theoretical models were developed across different fields to study users acceptance and use of technology. Social cognitive theory (SCT) is one of the fundamental theories that initiate the basics for studying human behaviour (Bandura, 1986 and Bandura \& McClelland 1977). This theory implies that individuals tend to learn from others through observation, direct experience, and human discussion and interaction. In 1995, Compeau and Higgins applied and extended SCT to the computer field but due to the nature of the model its usage was extended to the acceptance and use of information systems in general. This model examines two core cognitive constructs which were advanced as the major cognitive forces leading users' behaviour (Wood and Bandura, 1989). First, outcome expectations which mean individuals are more likely to accept behaviour that could result in positive consequences compared to other behaviour that will not result in favourable consequences. Second, self-efficacy which is an individual's belief about one's ability to perform a particular behaviour. These two constructs have been widely adopted by many behavioural acceptance theories using different terms such as perceived usefulness in the theory of technology acceptance model (TAM) (Davis et al., 1989) and Perceived Behavioural Control (PBC) in the theory of planned behaviour (TPB) (Ajzen, 1991), sequentially. In the TPB, PBC was defined as people's perception of the ease or difficulty associated with performing a behaviour of interest (Ajzen, 1991). This factor accounts for situations where an individual lacks confidence or does not have control over his behaviour (Yousafzai et al., 2010).

TAM is designed primarily for information systems (IS) contexts, to predict information technology acceptance and usage on the work environment (Davis et al., 1989). This theory posits that behavioural intention, which was proven to be directly affecting human behaviour (Fishbein and Ajzen, 1975), can be influenced by an individual's attitude towards using such technology or system. The attitude is impacted by two factors: 1) The perceived usefulness which is defined as the degree to which an individual believes that using a specific system would enhance their work performance, 2) The perceived ease of use which represents the degree to which a person believes that using a specific system would be free of efforts. The model was developed further by Venkatesh and Davis (2000) to incorporate the social influence construct (i.e., subjective norm, voluntariness, and image) and cognitive instrumental process variables (i.e. job relevance, output quality, result demonstrability, and perceived ease of use), and excludes 
attitude constructs.

In 2003, Venkatesh et al., (2003) presented a more integrated model of users acceptance of technology which tests and integrate eight different models, including TPB and TAM. The Unified Theory of Acceptance and Use of Technology (UTAUT) model consist of four main determinants of users behavioural intention ( performance expectancy, effort expectancy, social influence, and facilitating conditions). Performance expectancy explains the perception of usefulness, outcome expectations, relative advantage availability, and benefits, while Effort Expectancy expresses users' perception of the ease-of-use and complexity of using a system. On the other hand, social influence represents "the degree to which an individual perceives that important others believe he or she should use the new system"(Venkatesh et al., 2003). This factor is composed of other similar variables, including subjective norm and image. The last construct is "facilitating conditions" which is defined as "the degree to which an individual believes that an organizational and technical infrastructure exists to support the use of the system"(Venkatesh et al., 2003). This is particularly important as without having the proper infrastructure, the performance of such behaviour becomes challenging for many individuals. The UTAUT model also identified four moderators (i.e. age, gender, experience, and voluntariness of use) that influence the relationships between users' behavioural intention and the four primary constructs. This model managed to explain about $70 \%$ of the variance in users' behavioural intention to accept and use such technology which outweighs the variance explained by any previously discussed models. The UTAUT is a plausible model for testing factors impacting users' acceptance, use of e-government services (Zuiderwijk et al., 2015; AlAwadhi and Morris, 2008; Alshehri et al., 2012; Gupta et al., 2008), and m-government services (Abu-Shanab and Haider, 2015), while at the same time take into consideration social factor that impacts user's behaviour. This research extends the UTAUT (Venkatesh et al., 2003) to include two extra variables i.e. awareness and information quality, which are widely believed to impact citizens' intentions to adopt and use m-government services. The following section will show the modified model and propose hypotheses for this research.

\section{Research Model and Hypothesis Development}

To better reflect the context of the study, it is usually necessary to adjust the hypothesis underlying the UTAUT model. In this paper, the UTAUT model was amended based on prior literature about e-government and $\mathrm{m}$-government adoption studies and citizens behaviour to better reflect the context of $\mathrm{m}$-government adoption in the context of the KSA. The proposed research model for m-government adoption is shown in Fig. 1. The following sections demonstrate the model modifications, components and research hypotheses.

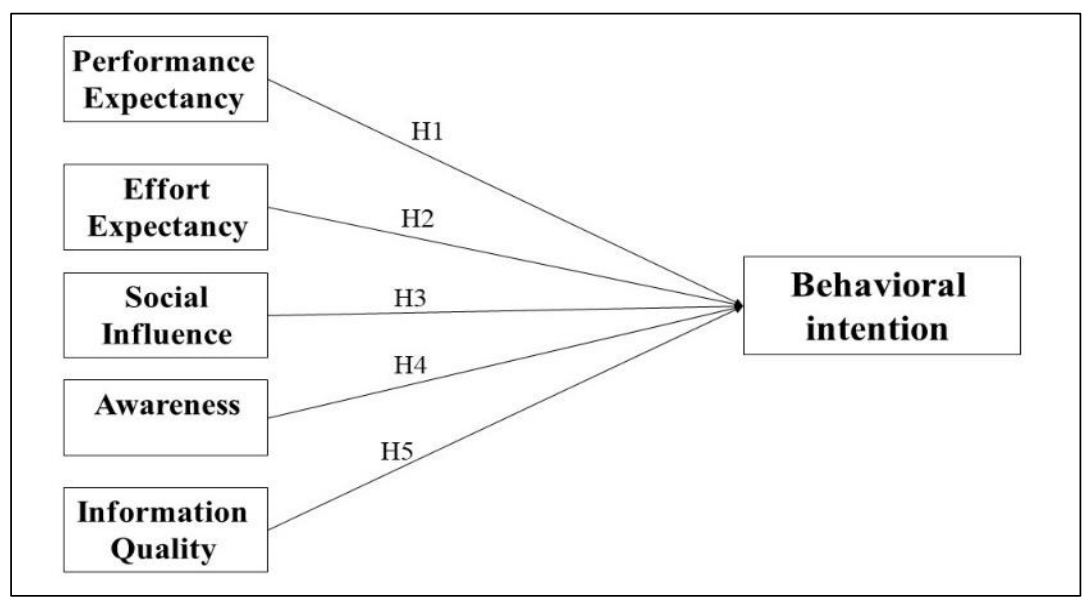

Figure 1. The proposed research model

\subsection{Performance Expectancy}

Venkatesh et al. (2003) defined performance expectancy as "the degree to which an individual believes that using the system will help him or her to attain gains in job performance" (p.447). Achieving better-valued outcomes is a strong motivation for someone to use such technology (Venkatesh and Speier, 1999, Davis et al., 1989). In the case of citizens adoption of m-government, this means that citizens are more likely to use the m-government services if this 
will give them a relative advantage compared to the traditional way of getting the service. For instance, if the users perceived that using the m-government services offers them a good quality of services that will lead the users to perform the service purely online in a short period, users will be more likely to use the app. Carter \& Belanger (2004) found that perceived usefulness and relative advantage were significant in increasing citizens' intention to use e-government in the United States of America. The same results were found valid in a study conducted in the context of United Kingdom (Carter \& Weerakkody, 2008), KSA (Alshehri et al., 2013), Jorden (Abu-Shanab and Haider, 2015), and Pakistan (Azam et al., 2013). According to Althunibat and Sahari (2011), performance expectancy is the most robust factor that impacts the adoption of several technologies and applications. Therefore, we hypothesized that:

Performance expectancy positively influences user's behavioural intention to use m-government services (Hypothesis 1).

\subsection{Effort Expectancy}

Having a useful system is not enough to ensure citizens usage of the provided m-government services. According to Davis et al. (1989), "even if potential users believe that a given application is useful, they may, at the same time, believe that the system is too hard to use and that the performance benefits of usage are outweighed by the effort of using the application". In order to use a technology or system, users should perceive it as free of effort. Several factors might impact users perception of how easy the use of such system or technology will be. For instance, finding the required government services online sometime becomes difficult because of the large number of provided government services. Also, the absence of help officers in the online environment makes the process of filling the form difficult for some individuals which can form a constraint to use the system. The design of the m-government services can reduce the effort needed to get access to the required services (Abanumy et al., 2005). Alshehri et al., (2012) found that effort expectancy significantly influences citizens behavioural intention to use e-government services. According to Al-Qeisi et al. (2015), effort expectancy is the key determinant of individuals behavioural intention to use such technology in the Arab world when the technology is classified as Internet-based. Therefore, the following hypothesis is proposed:

Effort expectancy will have a positive influence on users behavioural intention to use m-government services (Hypothesis 2)

\subsection{Social Influence}

As explained earlier, social influence concerns about others view of whether the user should or should not use the system. Social influence may come from any relative, friends, neighbours, work colleagues or even social media influencer who can alter an individual's behaviour. For example, in the case of using m-government services, elderly parents may use m-government services when their offspring believes it is important for them to use it. Venkatesh et al. (2003) and Davis et al. (1989) emphasised the important role of social influence in influencing user behavioural intention to use or accept such technology. Though Alshehri et al., (2012) found that social influence construct has no impact on citizens behavioural intention to accept e-government services in the KSA, we do expect that social influence will have a significant impact on citizens behavioural intention to use m-government services. Several studies conducted in the Arab region proved the positive role social influence played in influencing citizens behavioural intention to use m-government services (Abu-Shanab and Haider, 2015) Abdelghaffar and Magdy, 2012). Therefore, we hypothesised that:

Social influence will have a positive influence on users' behavioural intention to use m-government services (Hypothesis 3).

\subsection{Facilitating Conditions}

Drawing on prior research, the proposed model does not include facilitating conditions construct as research in the field of e-government adoption have shown that it is not the best predictor for citizens behavioural intention to use e-government services (Rana et al., 2012, Zuiderwijk et al., 2015). Venkatesh et al. (2003) stated that in the present of effort expectancy, facilitating condition has no significant impact on user's behavioural intention. Instead, facilitating conditions only have a direct influence on the user's actual usage behaviour. Therefore, as this study only concentrates in studying user's behavioural intention, this construct was not added to the proposed research model.

\subsection{Moderator Variables}

Venkatesh et al. (2003) emphasised the importance of considering the moderating variables to predict user's behavioural intention to adopt a technology. However, this study does not concentrate on the impact of these 
moderators on the proposed hypotheses. Several studies use UTAUT without studying the moderator variables and the model hypotheses still found valid (Pahnila et al., 2011, Mustafa et al., 2020). Therefore, this paper will not discuss the impact of these moderators on moderating the proposed hypotheses.

\subsection{Citizen Awareness}

According to Shareef et al., (2011), citizen awareness is defined as "gaining and acquiring knowledge, education, consciousness as much as users perceived to be sufficient to learn the characteristics of the system, use it with skill, and realize its strategic functionality and competitive advantage". Several studies emphasize the important role of citizen awareness in the adoption of m-government services (Shahzad et al., 2019); Abdelghaffar and Magdy, 2012; Pikkarainen et al., 2004). People need to be aware of the features and services so that they can utilize them (Y.-C. Chen \& Dimitrova, 2006). According to Mengistu et al., (2009) people awareness is considered as one of the pre-requisites for using government e-services which is one of the challenges on the developing countries since a large percentage of the population are not aware of the usefulness and benefits of the provided online government services. AlAwadhi \& Morris (2008) found that $87 \%$ of the Kuwaiti citizens were complaining of the lack of awareness of the e-government services. According to Sultana et al. (2016), lack of awareness represents a big challenge for the success of internet-based government services. Governments are responsible to promote m-government services and encourage citizens to utilise these services effectively (Al-Swidi and Faaeq, 2019). Since the user's adoption of m-government services is highly affected by awareness, the following hypothesis is proposed:

Citizen awareness will have positive influence on behavioural intention to use m-government services (Hypothesis 4).

\subsection{Information Quality}

Information quality refers to the provision of information that is accurate, updated, complete, organized and understandable which allows users to obtain their intended objectives (Shareef et al., 2011). Providing accurate information in delivering the service increases the level of transparency and trust in government functionality which in turn reduces the need for face to face interaction to complete the required services (Shahzad et al., 2019, Venkatesh et al., 2016). According to Chen et al., (2015), the adoption of the online government system services will be positively affected if the provided information is relevant and enough to accomplish the required task. The lack of information quality hinders people transformation toward the e-services (Lallmahomed et al., 2017). Stefanovic et al., (2016) and Wang and Liao (2008) both examined factors impacting citizens adoption of e-government services and found that information quality has a direct effect on the intention to use e-government services. Therefore, due to the important role of the information quality on the acceptance of internet-based government services, we hypothesis that:

Information quality will have positive influence on behavioural intention to use m-government services (Hypothesis 5)

\section{Methodology of Research}

\subsection{Instrument Development and Data Collection}

A structured survey questionnaire was developed to collect data from actual users of Absher application about the factors identified previously in the proposed model. Measurements of research constructs were developed based on pre-validated measures available on prior literature. Most of the measurement items were adopted from Venkatesh et al. (2003) (see Table 1) as the items were already tested and proved to be valid. All constructs items were rephrased to relate specifically to the context of m-government. A total of 19 constructs were used to measure both independent and dependent variables (excluding the demographics). A five-point Likert-type scale was used where 1 represents strongly disagree and 5 represents strongly agree. A pilot study was then conducted to ensure the validity, reliability and the clarity of the survey questions. The results of the pilot study were encouraging with all construct having Cronbach's Alpha value above 0.7 .

According to Weerakkody et al. (2013), the main users for m-government/e-government services are citizens. Therefore, the web-based questionnaire survey link was disseminated to the primary users of m-government services in the KSA (citizens and residences). Both users and non-users, of Absher application, are included in the sample. Participation in the study was voluntary and the respondents were randomly sampled. The survey was disseminated to about 1000 individuals and a follow-up reminder email was sent after 3 weeks to increase the likelihood of participation. We received 311 responses from participants of which 47 were discarded after data cleansing due to invalid or partial responses. Respondents selecting one option for answering all survey questions was considered invalid due to biased response. In total 264 responses have been used in the analysis for the model testing. The 
eligible response rate was about $26.4 \%$ which is considered proper for this study (Venkatesh et al., 2008). Table 2 shows the respondent demographic profile.

Table 1. Measurement items

\begin{tabular}{|c|c|c|c|}
\hline Construct & & Measure & Source \\
\hline $\begin{array}{l}\text { Citizens } \\
\text { Awareness }\end{array}$ & $\begin{array}{l}\text { CA1 } \\
\text { CA2 }\end{array}$ & $\begin{array}{l}\text { I am aware of the services offered by Absher application. } \\
\text { I do know the features and services offered on Absher } \\
\text { application. } \\
\text { I have come across government campaigns/advertisements } \\
\text { for using Absher application. }\end{array}$ & $\begin{array}{l}\text { Adapted from } \\
\text { ( Murru } \\
\text { (2003), } \\
\text { Anthopoulos } \\
\text { et al. (2007), } \\
\text { Shreef et al. } \\
\text { (2009) }\end{array}$ \\
\hline \multirow[t]{2}{*}{$\begin{array}{l}\text { Performance } \\
\text { Expectancy }\end{array}$} & PE1 & $\begin{array}{l}\text { I think Absher application provides useful service and } \\
\text { information to me. } \\
\text { I think Absher application enhances the effectiveness of my life } \\
\text { in general. }\end{array}$ & \multirow[t]{2}{*}{$\begin{array}{l}\text { Adapted from } \\
\text { (Venkatesh et } \\
\text { al., 2012) }\end{array}$} \\
\hline & PE3 & Using Absher application increases my productivity & \\
\hline $\begin{array}{l}\text { Effort } \\
\text { Expectancy }\end{array}$ & $\begin{array}{l}\text { EE2 } \\
\text { EE3 }\end{array}$ & $\begin{array}{l}\text { My interaction with Absher application is clear and } \\
\text { understandable. } \\
\text { I find Absher application easy to use. } \\
\text { Learning how to use Absher application is easy for me. }\end{array}$ & $\begin{array}{l}\text { Adapted from } \\
\text { (Venkatesh et } \\
\text { al., 2012) }\end{array}$ \\
\hline $\begin{array}{l}\text { Information } \\
\text { Quality }\end{array}$ & $\begin{array}{l}\text { IQ1 } \\
\text { IQ2 } \\
\text { IQ3 }\end{array}$ & $\begin{array}{l}\text { Information provided by Absher application is accurate } \\
\text { Information provided by Absher application is up-to-date } \\
\text { Information provided by Absher application meets my needs }\end{array}$ & $\begin{array}{l}\text { Adapted from } \\
\text { (Wang \& } \\
\text { Liao, 2008) }\end{array}$ \\
\hline Social Influence & SI1 & $\begin{array}{l}\text { People who are important to me think that I should use Absher } \\
\text { application } \\
\text { I will use Absher application if my friends use it. }\end{array}$ & $\begin{array}{l}\text { Adapted from } \\
\text { (Venkatesh et } \\
\text { al., 2012)) }\end{array}$ \\
\hline $\begin{array}{l}\text { Behavioral } \\
\text { Intention }\end{array}$ & $\begin{array}{l}\text { BI1 } \\
\text { BI2 } \\
\text { BI3 } \\
\text { BI4 } \\
\text { BI5 }\end{array}$ & $\begin{array}{l}\text { I plan to use Absher application. } \\
\text { I intend to use Absher application as much as possible. } \\
\text { I predict I well use Absher application in the coming months. } \\
\text { I would seriously contemplate using Absher application . } \\
\text { It is likely that I am going to use Absher application to request } \\
\text { government services }\end{array}$ & $\begin{array}{l}\text { Adapted from } \\
\text { (Venkatesh et } \\
\text { al., 2012)) }\end{array}$ \\
\hline
\end{tabular}

\subsection{Data Analysis}

Structure equation modelling (SEM) was used to test the proposed model and confirm the relationships among constructs. As the data size is relatively small $(\mathrm{n}=264)$, PLS-SEM was preferred due to its ability to give valid results when analysing sample size of more than 200 responses. The data were analysed using Smart PLS software to assess both the measurements and the structural model. A two-step approach proposed by Anderson and Gerbing (1988) was used. In the first step, the reliability and validity of the measurement model were assessed and in the second step, the structural model was examined to test the proposed hypotheses through the use of Partial Least Square technique.

\section{Results}

\subsection{Measurement Model}

Cronbach's alpha and composite reliability were measured to test the reliability of the used scales. According to Hair et al. (2010), variables with outer loading above 0.5 is considered acceptable while a value above 0.7 is considered highly satisfactory. The outer loadings of all measurement items were above 0.5 . Cronbach's alpha values for all the 
constructs were then measured. Table 3 shows that all constructs have a minimum threshold value of 0.7 except one construct. One item was removed from social influence construct to increase the Cronbach's alpha value. Thus, a higher Cronbach's alpha value of 0.6 was achieved. According to Taber (2017), Cronbach alpha value ranging between 0.6 and 0.7 indicates an acceptable level of reliability. Therefore, the social influence construct was maintained in this study. Composite reliability values for all constructs ranging from 0.834 to 0.926 were higher than the minimum accepted level of 0.7, indicating that the measurement items used in this research satisfies the recommendation level and shows a good level of reliability.

Table 2. Respondent demographics Profile

\begin{tabular}{llll}
\hline Demographics & & Frequency & Percentage \\
\hline Gender & female & 173 & 65.5 \\
\hline Age & male & 91 & 34.5 \\
\hline & 20 or less & 8 & 3.0 \\
\hline & 21 to 30 & 60 & 22.7 \\
\hline Educational level & 31 to 40 & 70 & 26.5 \\
\hline & 41 to 50 & 70 & 26.5 \\
\hline & above 50 & 56 & 21.2 \\
\hline high school & 38 & 14.4 \\
\hline computer experience & bachelor & 171 & 64.8 \\
\hline & master & 41 & 15.5 \\
\hline & doctorate & 14 & 5.3 \\
\hline & novice & 13 & 4.9 \\
\hline & low & 24 & 9.1 \\
\hline & intermediate & 68 & 25.8 \\
\hline & high & 65 & 24.6 \\
\hline & expert & 94 & 35.6 \\
\hline & & & \\
\hline & & 64 & \\
\hline
\end{tabular}

Fornell and Larcker (1981) scale were used to test the convergent and discriminant validity of the measurement model. Table 3 shows that the Average Variance Extracted (AVE) of the measurement items are between 0.62 and 0.75 which exceed the minimum value of 0.5 . Hence, the convergent validity of the measurement items is confirmed, Discriminant validity was assessed by comparing the square roots of the AVE to the inter-factor correlations between constructs. According to Fornell and Larcker (1981), if the square roots of the AVE are higher than the inter-construct correlations, then discriminant validity is supported. Table 3 shows that the square roots of the AVE (the diagonal cells) are higher than the inter-constructs correlations confirming that all constructs satisfied the condition of discriminant validity. 
Table 3. The measurement model statistics: reliability, correlation matrix, and discriminant validity

\begin{tabular}{|c|c|c|c|c|c|c|c|c|c|}
\hline & 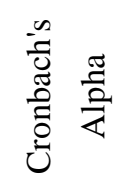 & 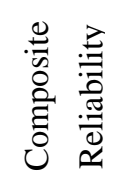 & $\sum_{\ll}^{\infty}$ & 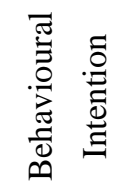 & 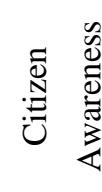 & 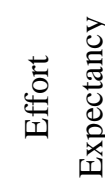 & 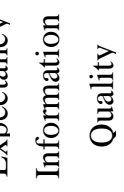 & 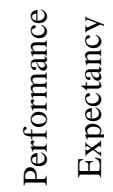 & 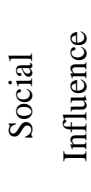 \\
\hline Behavioural Intention & 0.9 & 0.926 & 0.716 & 0.846 & & & & & \\
\hline Citizen Awareness & 0.7 & 0.834 & 0.628 & 0.427 & 0.792 & & & & \\
\hline Effort Expectancy & 0.842 & 0.904 & 0.759 & 0.589 & 0.549 & 0.871 & & & \\
\hline Information Quality & 0.77 & 0.867 & 0.685 & 0.516 & 0.481 & 0.622 & 0.827 & & \\
\hline Performance Expectancy & 0.783 & 0.873 & 0.697 & 0.607 & 0.535 & 0.63 & 0.655 & 0.835 & \\
\hline Social Influence & 0.6 & 0.809 & 0.683 & 0.672 & 0.403 & 0.495 & 0.436 & 0.523 & 0.827 \\
\hline
\end{tabular}

\subsection{Assessment of the Structural Model}

As the reliability and validity of the data were confirmed, the structural model was examined to verify the proposed hypotheses and test the established theoretical paths. Model prediction was evaluated using R-square (R2). The $\mathrm{R}$-square value represents the proportion of variant in the dependent variables that can be explained by one or more predictor variables. The variance demonstrated by the model in the individual's behavioural intention was 0.57 , showing a good predictive power of the proposed model. Figure 2 shows the path analysis, standardised estimates of beta coefficients and the R2 value. The beta coefficients results show a positive significant relationship between social influence and individual's behavioural intention to use m-government applications $(\beta=0.433, \mathrm{p}<0.001)$. Additionally, effort expectancy and performance expectancy were found positively influencing individual's behavioural intention to use m-government applications with beta coefficient values of $(\beta=0.213, p<0.01)$ and $(\beta=$ $0.204, \mathrm{p}<0.01)$ respectively. Thus, this proving the validity of H1, H2, and H3. In contrast, citizens awareness and information quality were not found to influence individuals' behavioural intention to use m-government application since their beta coefficient value was low $(\beta=0.003, p>0.05)$ and $(\beta=0.062, p>0.05)$ respectively. Therefore, $\mathrm{H} 4$ and $\mathrm{H} 5$ were rejected. Table 4 shows the results of all the tested hypotheses.

Table 4. Overview of the hypotheses test results

\begin{tabular}{llllll}
\hline $\begin{array}{l}\text { Hypotheses } \\
\text { number }\end{array}$ & Hypotheses & $\beta$ & T-value & P-Values & $\begin{array}{l}\text { Supported/ } \\
\text { not supported }\end{array}$ \\
\hline H1 & Performance Expectancy -> Behavioural Intention & 0.213 & 3.063 & 0.002 & supported \\
H2 & Effort Expectancy -> Behavioural Intention & 0.204 & 3.242 & 0.001 & supported \\
H3 & Social Influence -> Behavioural Intention & 0.433 & 7.218 & 0.000 & supported \\
H4 & Citizen Awareness -> Behavioural Intention & 0.003 & 0.069 & 0.945 & Rejected \\
H5 & Information Quality -> Behavioural Intention & 0.062 & 0.929 & 0.353 & Rejected \\
\hline
\end{tabular}




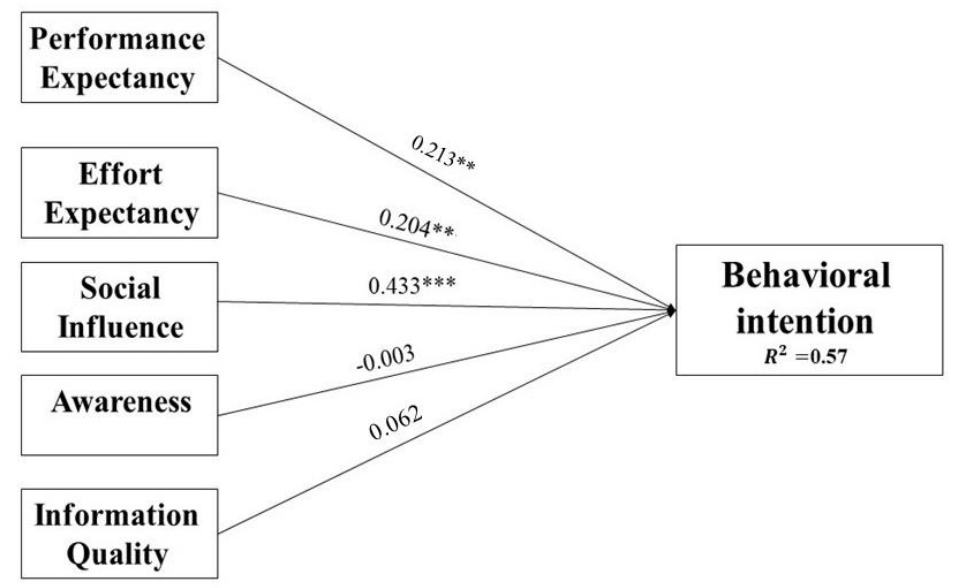

Figure 2. PLS results for hypotheses testing (Note: ${ }^{*} \mathrm{p}<0.05,{ }^{*} \mathrm{p}<0.01, * * * \mathrm{p}<0.001$ )

\section{Discussion and Implications}

The results from the path analysis provide evidence that the social influence has the most substantial effect on individual's behavioural intention beside performance and effort expectancies, which gives it a high priority among the other proposed variables. These findings imply that user's behavioural intention toward using m-government applications will be affected by the behaviour of their important others such as family and friends. According to Hofstede et al. (2010) the Saudi society considered as a collectivist society, where people are profoundly affected by their family, extended family, or extended relationships. This indicates that there is a need to convince the social circle surrounding targeted individuals of the importance of using m-government applications as a channel for getting access to government services. Social media and influencers can also be employed to convince and persuade their followers of the benefits of using m-government applications. Social strategy can also be applied to encourage the community to use m-government services.

The second predictor of an individual's behavioural intention to use m-government applications was performance expectancy. The use of m-government applications increases the effectiveness of the citizen's lives and enhance their productivity. It allows citizens to perform their transactions by several clicks on their smart devices which save time, cost, and effort. This result supports the findings of previous studies about the use of m-government applications in developing countries, such as Abu-Shanab (2014), which found that performance expectancy is one of the most significant constructs to be considered. Therefore, the result may direct government agencies and decision-makers to support m-government services that emphasise the delivery of useful applications.

The third predictor of user's behavioural intention to use m-government applications was effort expectancy. Using easy to use system facilitates the process of performing the required tasks. Increasing the level of difficulty will form a barrier for using the m-government application and will result in a decrease in the acceptance of using m-government applications. Government decision-makers and developers of m-government applications should emphasise the importance of applying strategies that reduce the effort required to use the system. For instance, applying digital access portal where users can use a unified sign-in detail to access all forms of electronic government services will reduce the number of efforts required to sign up for different electronic government portals. The design should be user-centric where individuals needs are reflected in the design. This will enrich the experience and encourage users to reuse the system.

\subsection{Conclusion and Future Work}

The main objective of this paper was to examine factors influencing citizen's behavioural intention to use m-government application. The study extended the unified theory of acceptance and use of technology UTAUT to include other factors, i.e. citizen awareness and information quality, due to their importance on the adoption of m-government applications. However, after testing the model in the context of the KSA using a sample size of 264 respondents, the study only confirmed the significance of factors in the original UTAUT model while rejecting the 
other factors added to extend the model. In particular, the findings revealed that social influence, performance expectancy and effort expectancy were the only significant factors that impact citizens adoption of m-government applications in the KSA. Citizen awareness and information quality were interestingly found not significant. Therefore, it proved the validity of using the UTAUT model in predicting citizen's adoption of m-government applications. However, since the data was collected only from potential users of Absher m-government application, there is a need to consider testing the insignificant factors in the case of other m-government applications as different systems at different stages of development and different time periods may have yielded different responses.

In conclusion, despite the limitation of this study, this research fills the gap related to the lack of studies exploring factors impacting the adoption of m-government applications in Saudi Arabia. It gives government agencies a good insight into factors that are important to be considered when provisioning m-government services. The outcome of this study can also be used by other researchers to test the adoption of $\mathrm{m}$-government services in other developing countries.

\section{References}

Abanumy, A., Al-Badi, A., \& Mayhew, P. (2005). e-Government Website accessibility: in-depth evaluation of Saudi Arabia and Oman. The Electronic Journal of e-government, 3(3), 99-106.

Abdelghaffar, H., \& Magdy, Y. (2012). The Adoption of Mobile Government Services in Developing Countries: The Case of Egypt, 2(4), 9.

Absher Home. (2018). Retrieved October 3, 2018, from https://mub.me/GZr

Abu-Shanab, E. (2014). Antecedents of trust in e-government services: An empirical test in Jordan. Transforming Government: People, Process and Policy, 8(4), 480-499. https://doi.org/10.1108/TG-08-2013-0027

Abu-Shanab, E., \& Haider, S. (2015). Major factors influencing the adoption of m-government in Jordan. Electronic Government, an International Journal, 11(4), 223-240.

Ajzen, I. (1991). The theory of planned behavior. Organizational Behavior and Human Decision Processes, 50(2), 179-211.

AlAwadhi, S., \& Morris, A. (2008). The Use of the UTAUT Model in the Adoption of E-Government Services in Kuwait. Proceedings of the 41st Annual Hawaii International Conference on System Sciences (HICSS 2008), pp. 219-219. https://doi.org/10.1109/HICSS.2008.452

Al-Khateeb, A., Faloudah, A., Bahumayd, M., \& Zafar, A. (2015). E-Government Strategy and its impact on Economic Development of the Nation: A Case Study of the KSA. IARJSET, 2(5), 105-110. https://doi.org/10.17148/IARJSET.2015.2522

Alshehri, M., Drew, S., \& AlGhamdi, R. (2012). E-Government Services: Applying the Utaut Model, 8.

Alshehri, M., Drew, S., \& Alghamdi, R. (2013). Analysis of citizens acceptance for e-government services: applying the UTAUT model. arXiv preprint arXiv:1304.3157.

Al-Swidi, A. K., \& Faaeq, M. K. (2019). How robust is the UTAUT theory in explaining the usage intention of e-government services in an unstable security context?: A study in Iraq. Electronic Government, an International Journal, 15(1), 37-66.

Althunibat, A., \& Sahari, N. (2011). Modelling the factors that influence mobile government services acceptance. African Journal of Business Management, 5(34), 13030-13043.

Anthopoulos, L. G., Siozos, P., \& Tsoukalas, L. A. (2007). Applying Participatory Design and Collaboration in Digital Public Services for Discovering and Re-designing E-government Services. Government Information Quarterly, 24(2), 353-376.

Azam, A., Qiang, F., \& Abdullah, M. I. (2013). Determinants of e-government services adoption in Pakistan: an integrated model. Electronic Government, an International Journal, 10(2), 105-124.

Bandura, A., \& Mccleland, D. C. (1977). Social learning theory.

Bandura, A. (1986). Fearful expectations and avoidant actions as coeffects of perceived self-inefficacy.

Bulletin of Individuals and Households' ICT Access and Usage Survey. (2018). Retrieved from https://www.stats.gov.sa/sites/default/files/bulletin_of_individuals_and_households_ict_2018.pdf

Carter, L., \& Belanger, F. (2004). Citizen Adoption of Electronic Government Initiatives. The Hawaii International Conference on System Sciences, 10. 
Carter, L., \& Weerakkody, V. (2008). E-government adoption: A cultural comparison. Information Systems Frontiers, 10(4), 473-482. https://doi.org/10.1007/s10796-008-9103-6.

Chen, J. V., Jubilado, R. J. M., Capistrano, E. P. S., \& Yen, D. C. (2015). Factors affecting online tax filing - An application of the IS Success Model and trust theory. Computers in Human Behavior, 43, $251-262$. https://doi.org/10.1016/j.chb.2014.11.017.

Chen, Y.-C., \& Dimitrova, D. V. (2006). Electronic Government and Online Engagement: Citizen Interaction with Government via Web Portals. International Journal of Electronic Government Research, 2(1), 54-76. https://doi.org/10.4018/jegr.2006010104.

Compeau, D. R., \& Higgins, C. A. (1995). Computer self-efficacy: Development of a measure and initial test. Mis Quarterly, 19(2), 189-211.

Davis, F. D., Bagozzi, R. P., \& Warshaw, P. R. (1989). User Acceptance of Computer Technology: A Comparison of Two Theoretical Models. Management Science, 35(8), 982-1003. https://doi.org/10.1287/mnsc.35.8.982.

eGovernment, S. (2018). Saudi-National Portal-Main. Retrieved October 17, 2018, from https://www.saudi.gov.sa/wps/portal/snp/main

Fang, Z. (2002). E-Government in Digital Era: Concept, Practice, and Development, 10, 22.

Figures and Statistics. (2017). Retrieved October 3, 2018, from https://mub.me/MdK9

Fishbein, M., \& Ajzen, I. (1975). Belief, attitude, intention and behaviour: An introduction to theory and research. Reading, Mass, Addison-Wesley.

Gupta, B., Dasgupta, S., \& Gupta, A. (2008). Adoption of ICT in a government organization in a developing country: An empirical study. The Journal of Strategic Information Systems, 17(2), $140-154$. https://doi.org/10.1016/j.jsis.2007.12.004

Isaac, W. C. (2007). Performance Measurement for the e-Government Initiatives: A Comparative Study, 204.

Lallmahomed, M. Z. I., Lallmahomed, N., \& Lallmahomed, G. M. (2017). Factors influencing the adoption of e-Government services in Mauritius. Telematics and Informatics, 34(4), 57-72. https://doi.org/10.1016/j.tele.2017.01.003

Laynea, K., \& Leeb, J. (2001). Developing Fully Functional E-Government: A Four Stage Model. Government Information Quarterly, 18(2), 122-136.

Media Center | General Authority for Statistics. (2017). Retrieved October 3, 2018, from https://www.stats.gov.sa/en/media-center

Mengistu, D., Zo, H., \& Rho, J. J. (2009). M-government: Opportunities and Challenges to Deliver Mobile Government Services in Developing Countries. 2009 Fourth International Conference on Computer Sciences and Convergence Information Technology, pp. 1445-1450. https://doi.org/10.1109/ICCIT.2009.171

Murru, M. L. (2003). E-Government: From real to virtual democracy (p. 5). Brussels: Boston University.

Mustafa, A., Ibrahim, O., \& Mohammed, F. (2020). E-government adoption: a systematic review in the context of developing nations. International Journal of Innovation, 8(1), 59-76.

Pahnila, S., Siponen, M., \& Zheng, X. (2011). Integrating Habit into UTAUT: The Chinese eBay Case. Pacific Asia Journal of the Association for Information Systems, 3(2).

Pikkarainen, T., Pikkarainen, K., Karjaluoto, H., \& Pahnila, S. (2004). Consumer acceptance of online banking: An extension of the technology acceptance model. Internet Research, 14(3), 224-235. https://doi.org/10.1108/10662240410542652

Rana, N. P., Williams, M. D., Dwivedi, Y. K., \& Williams, J. (2012). Theories and theoretical models for examining the adoption of e-government services. e-Service Journal: A Journal of Electronic Services in the Public and Private Sectors, 8(2), 26-56.

Shahzad, F., Xiu, G., Khan, I., \& Wang, J. (2019). m-Government security response system: predicting citizens' adoption behavior. International Journal of Human-Computer Interaction, 35(10), 899-915.

Shareef, M. A., Kumar, U., Kumar, V., \& Dwivedi, Y. K. (2009). Identifying critical factors for adoption of e-government. Electronic Government: An International Journal, 6(1), 70-96.

Shareef, M. A., Kumar, V., Kumar, U., \& Dwivedi, Y. K. (2011). e-Government Adoption Model (GAM): Differing service maturity levels. Government Information Quarterly, 28(1), 17-35. 
https://doi.org/10.1016/j.giq.2010.05.006

Sharma, S. K., Al-Badi, A., Rana, N. P., \& Al-Azizi, L. (2018). Mobile applications in government services (mG-App) from user's perspectives: A predictive modelling approach. Government Information Quarterly, 35(4), 557-568. https://doi.org/10.1016/j.giq.2018.07.002

Stefanovic, D., Marjanovic, U., Delić, M., Culibrk, D., \& Lalic, B. (2016). Assessing the success of e-government systems: An employee perspective. Information \& Management, 53(6), 717-726. https://doi.org/10.1016/j.im.2016.02.007

Sultana, M. R., Ahlan, A. R., \& Habibullah, M. (2016). A Comprehensive Adoption Model of M-Government Services Among Citizens In Developing Countries. Journal of Theoretical \& Applied Information Technology, 90(1).

Taber, K. S. (2017). The Use of Cronbach's Alpha When Developing and Reporting Research Instruments in Science Education. Research in Science Education. https://doi.org/10.1007/s11165-016-9602-2

UN E-Government Survey 2018. (2018). Retrieved October 29, 2018, from https://publicadministration.un.org/egovkb/en-us/Reports/UN-E-Government-Survey-2018

Venkatesh, M. D., \& Davis. (2003). User Acceptance of Information Technology: Toward a Unified View. MIS Quarterly, 27(3), 425. https://doi.org/10.2307/30036540

Venkatesh, V., \& Davis, F. D. (2000). A Theoretical Extension of the Technology Acceptance Model: Four Longitudinal Field Studies. Management Science, 46(2), 186-204.

Venkatesh, V., Brown, S. A., Maruping, L. M., \& Bala, H. (2008). Predicting different conceptualizations of system use: The competing roles of behavioral intention, facilitating conditions, and behavioral expectation. Management Information Systems Quarterly, 32(3), 483-502.

Venkatesh, V., Thong, J. Y., Chan, F. K., \& Hu, P. J. (2016). Managing citizens' uncertainty in e-government services: The mediating and moderating roles of transparency and trust. Information Systems Research, 27(1), $87-111$.

Venkatesh, V., Thong, J., \& Xu, X. (2012). Consumer Acceptance and Use of Information Technology: Extending the Unified Theory of Acceptance and Use of Technology. Management Information Systems Quarterly, 36(1), 157-178.

Wang, Y.-S., \& Liao, Y.-W. (2008). Assessing eGovernment systems success: A validation of the DeLone and McLean model of information systems success. Government Information Quarterly, 25(4), 717-733. https://doi.org/10.1016/j.giq.2007.06.002

Weerakkody, V., El-Haddadeh, R., Al-Sobhi, F., Shareef, M. A., \& Dwivedi, Y. K. (2013). Examining the influence of intermediaries in facilitating e-government adoption: An empirical investigation. International Journal of Information Management, 33(5), 716-725.

Wood, R., \& Bandura, A. (1989). Social Cognitive Theory of Organizational Management. The Academy of Management Review, 14(3), 361. https://doi.org/10.2307/258173

Yasser. (2016). Retrieved 14 July 2018, from https://www.yesser.gov.sa/

Yousafzai, S. Y., Foxall, G. R., \& Pallister, J. G. (2010). Explaining Internet Banking Behavior: Theory of Reasoned Action, Theory of Planned Behavior, or Technology Acceptance Model?: Internet Banking Behavior. Journal of Applied Social Psychology, 40(5), 1172-1202. https://doi.org/10.1111/j.1559-1816.2010.00615.x

Zuiderwijk, A., Janssen, M., \& Dwivedi, Y. K. (2015). Acceptance and use predictors of open data technologies: Drawing upon the unified theory of acceptance and use of technology. Government Information Quarterly, 32(4), 429-440.

\section{Copyrights}

Copyright for this article is retained by the author(s), with first publication rights granted to the journal.

This is an open-access article distributed under the terms and conditions of the Creative Commons Attribution license (http://creativecommons.org/licenses/by/4.0/). 